\title{
Quantity versus Quality in Off-Street Parking Requirements
}

\author{
Vinit Mukhija and Donald Shoup
}

Most local governments' off-street parking requirements promote quantity over quality, focusing on ensuring an ample supply of parking. This has undesirable consequences for the built environment. Parking lots and parking structures routinely overwhelm the architecture and urban design of even the best buildings and neighborhoods. We argue that planners should worry less about the quantity of parking, and pay more attention to its quality. Through examples of zoning reforms adopted by some cities, we show how regulating the quality of parking has the potential to improve urban design.

Vinit Mukhija (vmukhija@ucla.edu) is an assistant professor of urban planning at the University of California, Los Angeles (UCLA). He is an architect and planner, and his research focuses on housing and the built environment. He is the author of Squatters as Developers? Slum Redevelopment in Mumbai (Ashgate, 2003). Donald Shoup, FAICP (shoup@ucla .edu) is a professor of urban planning at UCLA. His recent research has centered on parking as a key link between land use and transportation. In 2005 the American Planning Association published his book, The High Cost of Free Parking.

Journal of the American Planning Association, Vol. 72, No. 3, Summer 2006.

(C) American Planning Association, Chicago, IL.

M ost local off-street parking requirements emphasize quantity over quality. Local governments often have minimum parking requirements that overwhelm the physical landscape with an excessive supply of unattractive parking, ${ }^{1}$ but relatively few impose design requirements on parking lots and parking structures. Off-street parking requirements focus on the ratio of parking spaces to floor area, usually neglecting the consequences for urban design. As a result, most parking lots are asphalt breaks in the urban fabric, and most parking structures present blank walls to the street. Parking lots and garages tend to interrupt the streetscape, expand the distances between destinations, and undermine walkability (see Figures 1 and 2). We argue that planners should worry less about the quantity of parking provided and should pay more attention to its quality.

Off-street parking requirements also reduce architectural quality. Architects often complain that they must shoehorn a building into the space remaining after the parking requirement has been satisfied, compromising the design. Thus reducing or removing parking requirements can make better design possible, and cities can use quality-based parking requirements within an urban design framework to reinforce the desired character of each neighborhood.

The market gives developers a strong incentive to provide adequate parking because lenders are unwilling to finance projects with inadequate parking and tenants are unwilling to rent space in them. But the market provides less incentive to improve parking design because many of the benefits of better parking design accrue to the community rather than to the property owner. Developers are more likely to spend money on a marble-veneered lobby (which will increase the value of the building) than on landscaping the parking lot (which will increase the value of the whole neighborhood).

In this article we show how planners can use the following five strategies to improve urban design.

1. Deregulate or limit the number of parking spaces.

2. Improve the location of parking.

3. Improve the design of surface parking.

4. Improve the design of parking structures.

5. Improve the design of residential garages. 


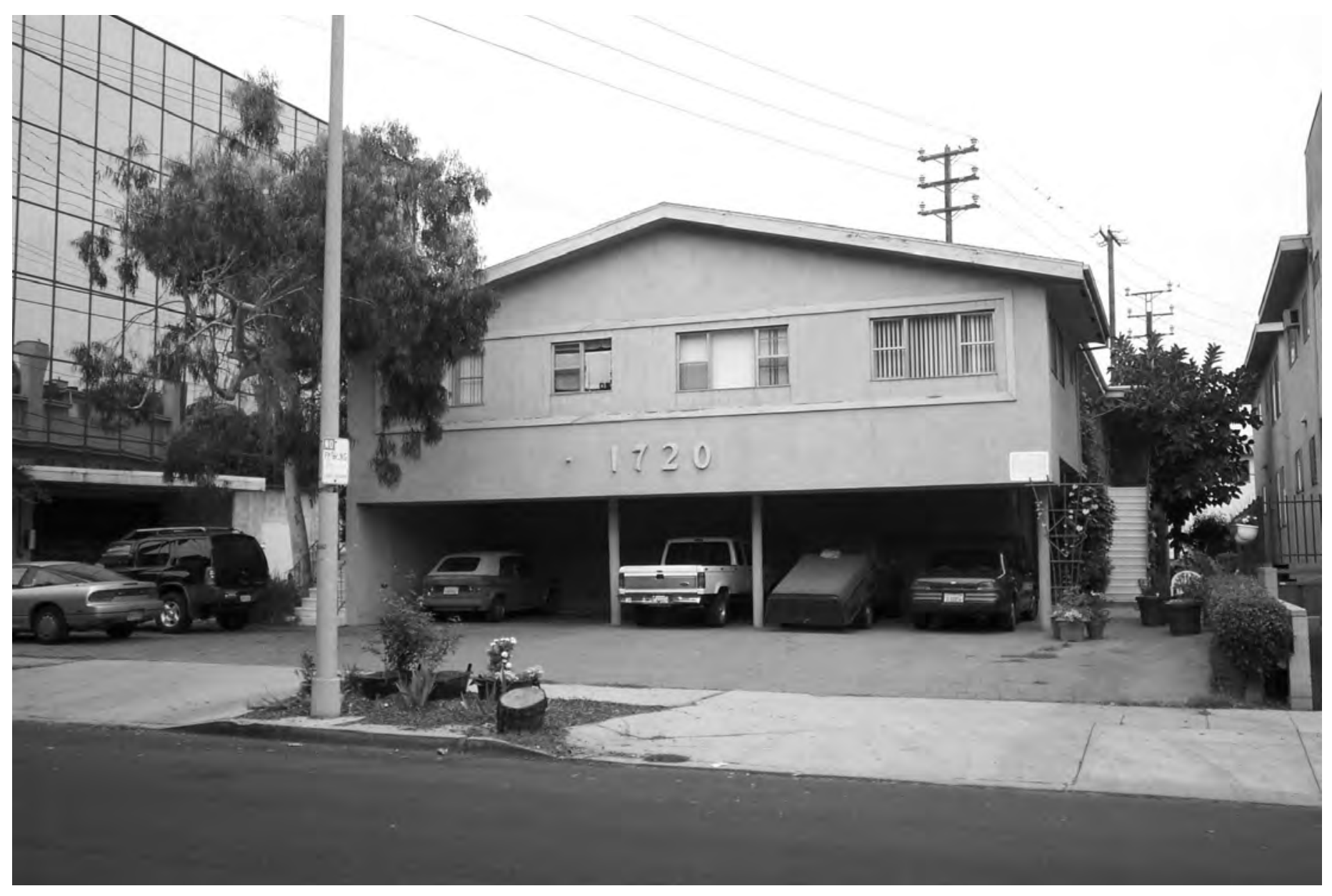

Figure 1. Off-street parking in Los Angeles.

Shifting the focus of parking requirements from quantity to quality will help planners to play a more constructive role in shaping the built environment.

\section{Eliminating Minimum Off-Street Parking Requirements}

Minimum parking requirements in zoning ordinances would not be needed if they did not increase the parking supply beyond what the market would provide (Shoup, 2005). Such requirements create a self-perpetuating cycle in which increasing the supply of parking leads to increased demand. Plentiful parking encourages people to buy more cars, and more cars lead cities to require even more parking spaces. Parking lots consume land that could be put to higher-value uses, such as housing, and they detract from the traditional pedestrian ambience of cities. As Alexander, Ishikawa, and Silverstein (1977) wrote 30 years ago:
We suspect that when the density of cars passes a certain limit, and people experience the feeling that there are too many cars, what is really happening is that subconsciously they feel that the cars are overwhelming the environment, that the environment is no longer "theirs," that they have no right to be there, that it is not a place for people, and so on. After all, the effect of the cars reaches far beyond the mere presence of the cars themselves. They create a maze of driveways, garage doors, asphalt and concrete surfaces, and building elements which people cannot use. When the density goes beyond the limit, we suspect that people feel the social potential of the environment has disappeared. (p. 122)

To preserve and enhance walkability, Alexander and his coauthors suggested that only $9 \%$ of a city's land should be devoted to parking, though there is little empirical basis for this number. Some cities, such as Cleveland, Milwaukee, and Philadelphia, have eliminated parking requirements in 


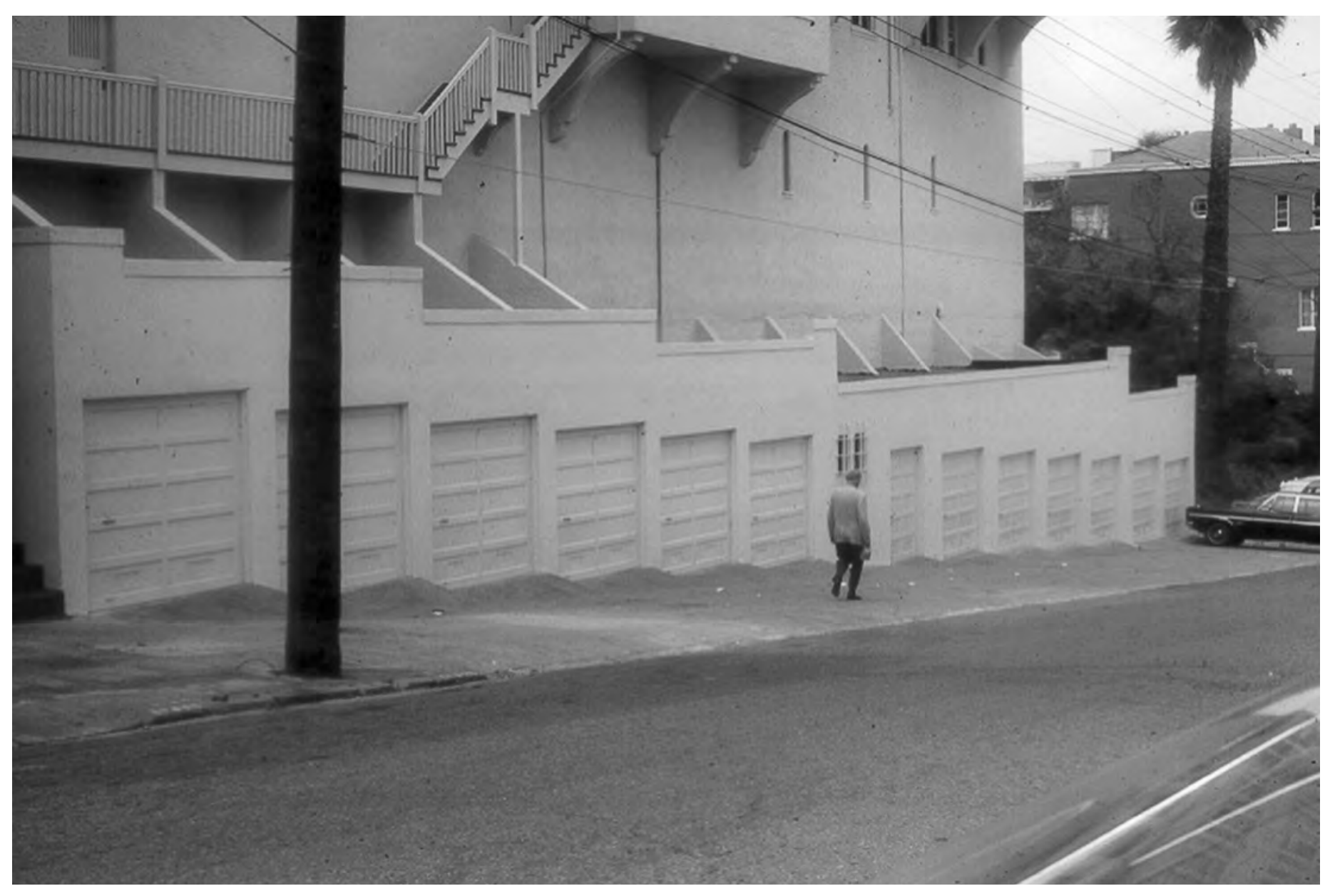

Figure 2. Off-street parking in San Francisco.

Source: San Francisco Planning Department

their downtowns to make them more accommodating to pedestrians. Other cities have reduced or eliminated parking requirements adjacent to public transit stops. An ordinance in Portland, Oregon states, "There is no minimum parking requirement for sites located less than 500 feet from a transit street with 20-minute peak hour service" (City of Portland, 2006).

Removing off-street parking requirements can also ease adaptive reuse and historic preservation. Older buildings rarely meet current minimum parking requirements, and as a consequence many stunning buildings are demolished and replaced by ordinary structures that do meet the requirements. Apart from the irreplaceable loss of heritage, such demolition limits the possibility of a rich and varied collage of buildings from different time periods. ${ }^{2}$ To encourage the conversion of older, economically distressed office buildings to apartments and lofts, some cities exempt these buildings from parking requirements if they are converted to residential uses. Los Angeles, for example, does not require downtown buildings built before 1974 to add parking spaces if they are converted to dwelling units, guest rooms, or joint live-work quarters. ${ }^{3}$

Minimum parking requirements are intended to ensure an ample parking supply, and they imply that parking is a problem only when there is not enough of it. But too much parking also creates problems. Most major U.S. cities, including Boston, Chicago, New York, and San Francisco, regulate the maximum rather than the minimum number of parking spaces in their downtowns. Carmel, California, which is famous for its attractive downtown, is an extreme, but highly successful, example of limits on parking. Zoning helps to maintain Carmel's unique pedestrian ambience by prohibiting off-street parking spaces in the central commercial district:

On-site parking is prohibited in the central commercial (CC) land use district. This policy reduces the need for curb cuts in sidewalks and the interference with free pedestrian traffic flow that would result from an excessive number of driveways. This policy is intended 
to enhance the opportunities for creating intra-block courts and walkways between properties and buildings. ${ }^{4}$ (City of Carmel-by-the-Sea, 1998b)

The absence of off-street parking (and of cars driving across the sidewalks to reach it) helps make Carmel one of the best places in America to be a pedestrian, and people from all over the world come to walk around (see Figure 3). Few cities will want to prohibit off-street parking, and many may not want to limit it, but they may wish to restrict surface parking lots, as in downtown San Francisco: "No permanent parking lot shall be permitted in [downtown]; temporary parking lots may be approved as conditional uses ... for a period not to exceed two years from the date of approval" (City of San Francisco, 2006).

Even without reducing their off-street parking requirements, cities like Palo Alto and Pasadena in California have improved urban design by offering developers the opportunity to pay a fee in lieu of providing all the parking spaces required by zoning. The cities then use the revenue to provide shared public parking spaces to replace those the developers would have provided. Public parking spaces built with the in-lieu revenue allow drivers to park once and visit multiple sites on foot, reducing vehicle traffic and increasing foot traffic. The in-lieu option makes it easier to restore historic buildings and rehabilitate historic areas for the reasons noted earlier. And because developers can meet their parking requirements without on-site parking, storefronts can be continuous, without the gaps that parking lots create. Developers can also undertake infill projects without assembling large parcels for on-site parking, and architects have greater design freedom. The public parking structures consume less land than if each development provided its own parking lot, and cities can place the structures where they interfere least with vehicle and pedestrian circulation. To improve the streetscape, some cities dedicate the first floor of public parking structures to retail uses. The in-lieu policy thus contributes to a better looking, safer, and more walkable city.

Some cities allow shared parking among sites where the peak parking demands occur at different times (e.g., banks and bars). Fewer spaces are needed to meet the combined peak demand, and each parking space is occupied more of the time. ${ }^{5}$ For example, Circle Centre, a successful retail/ entertainment development in downtown Indianapolis, would have needed 6,000 parking spaces if it were built with unshared parking for every individual use, but only 2,815 shared parking spaces were sufficient to meet the demand (Smith, 1996).

Removing or reducing off-street parking requirements does not restrict parking or reduce the market incentive for developers to provide an adequate supply. Letting markets determine the number of off-site parking spaces changes, but does not eliminate, planning for parking. Local governments should still regulate parking landscaping, layout, location, pedestrian access, provisions for the handicapped, security, setback, signage, storm water runoff, and urban design. The following section discusses ways to improve urban design by regulating the location and appearance of parking spaces.

\section{Parking Location Requirements}

The location and placement of parking greatly affects urban design. Parking lots located between the sidewalk and buildings make walking more onerous. To avoid this, planners can use conventional zoning regulations to require that parking be positioned below, behind, or beside buildings, rather than in front, and that buildings be oriented to the sidewalk.

Although Los Angeles did not begin to require off-street parking for retail and commercial buildings until 1946, cars and parking transformed the character of its commercial spaces in the first half of the 20th century. Richard Longstreth documented these changes. His work explains how merchants valued the sidewalk orientation of their businesses. Faced with an increase in the demand for parking, merchants initially provided parking spaces behind their buildings. Thus, major retail corridors like Wilshire Boulevard "maintained a sense of street-front drama by adhering to the pattern of showing facades and offering rear parking" (Longstreth, 1992, p. 152). Wilshire Boulevard set an example of pedestrian orientation for the region's smaller retail precincts during the 1930s and 1940s, but merchants finally abandoned pedestrians to make life more convenient for motorists and, as Liebs (1985) wrote, "the long-standing tenet of Main Street commercial site planning-line the shops along the sidewalk with room for parking only at the curb-was finally cast aside" (p. 14).

In a Planning Advisory Service report on how to prepare zoning ordinances, Lerable (1995) showed how the placement of parking lots can influence the pedestrian quality of the streetscape. The bottom panel of Figure 4 illustrates his recommended approach, placing parking lots behind buildings so that the only gap between shops is the access to parking. An even more desirable approach would close all gaps between the shops and provide access to the parking lot from a side street or rear alley. This would eliminate curb cuts on the main street, reduce driving across sidewalks to access the off-street parking, and allow the maximum amount of curb parking. Curb parking buffers the pedestrian 


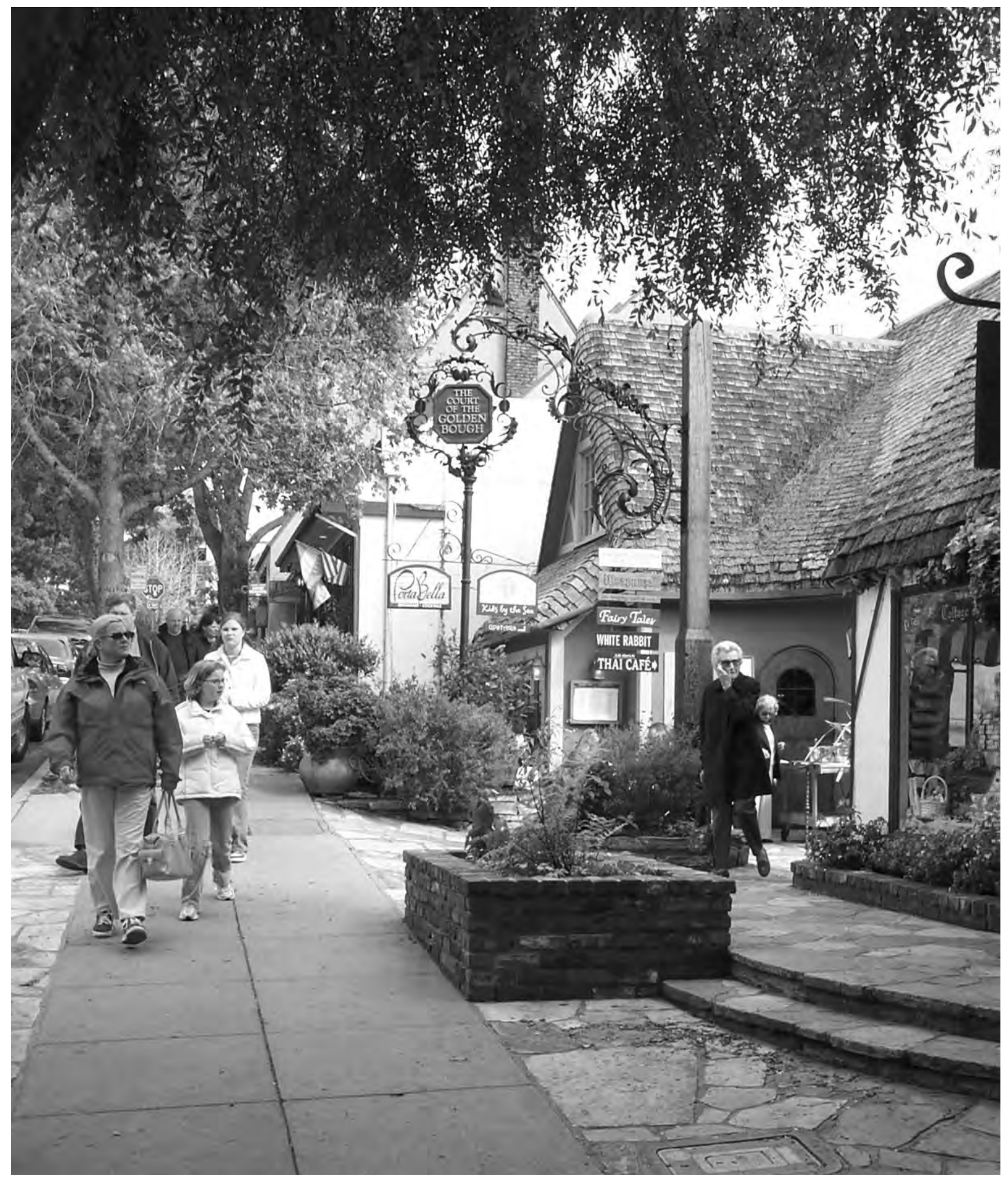

Figure 3. Walking in downtown Carmel. 
from cars and other vehicles on the street, and improves the walking experience on the sidewalk.

Similar ideas are popular with new urbanist architects and planners (Calthorpe, 1993). New urbanists sometimes go so far as to recommend a specific building typology, such as a colonnaded arcade, in order to respect the streetscape and push parking behind the buildings. A less prescriptive method is the use of build-to lines, the opposite of setback lines. Whereas setbacks ensure that buildings are placed at least a specified distance back from the street, build-to lines require that buildings come up to a specified plane, usually the sidewalk. New York's Lower Manhattan Plan pioneered the use of build-to lines to define visual corridors and maintain street front continuity (Barnett, 1974).

Regulations on the location of parking should not be implemented uniformly across a city, but should match a larger urban design strategy that recognizes the differing characters of neighborhoods. The city of SeaTac, Washington, for example, focuses on developing pedestrian-friendly commercial districts. It prohibits parking lots from dominating the streets in the commercial districts: "No parking shall be located between the building and the front property line. On corner lots, no parking shall be located between the building and either of the two (2) front property lines" (City of SeaTac, 2006). ${ }^{6}$ Such ideas are valuable outside commercial areas as well. In West Hollywood, California, zoning prohibits the use of a residential front yard for parking:

Automobiles shall not be parked between the street property line and the front of a residential unit except on a driveway leading to a garage or carport, or a semicircular driveway on a lot that has a minimum frontage width of seventy feet.' (City of West Hollywood, 2006a)

Such requirements help put on-site parking spaces beside or behind buildings, rather than in front, and can be combined with some of the design improvement strategies we discuss in the next section.

\section{Design Improvement Requirements}

Rather than focus on individual land uses, planning for parking should actively shape public space. The following strategies show how cities can improve the design of surface parking, parking structures, and residential parking.

\section{Improved Design of Surface Parking}

Because of their ubiquity, parking lots create great problems for urban design. They will continue to be built,

\section{Parking Lot Guidelines}

\section{LOCATION OF PARKING ON \\ COMMERCIAL STREETFRONTS}

Parking on a commercial streetfront should be minimized and where possible should be located behind a building. Parking located along a commercial streetfront where pedestrian traffic is desirable lessens the attractiveness of the area to pedestrians and compromises the safety of pedestrians along the street.

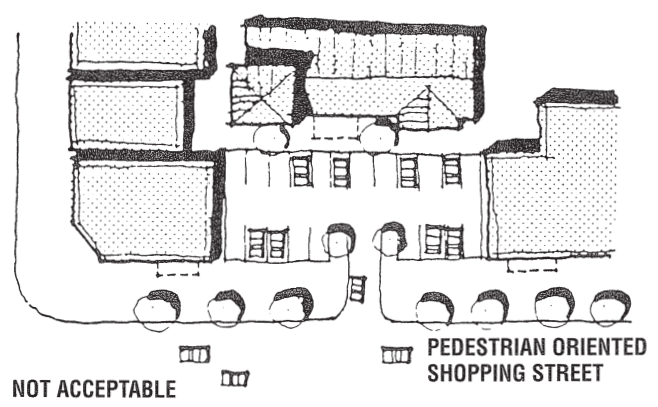

Parking lots along the full length of the streetfront are generally inappropriate

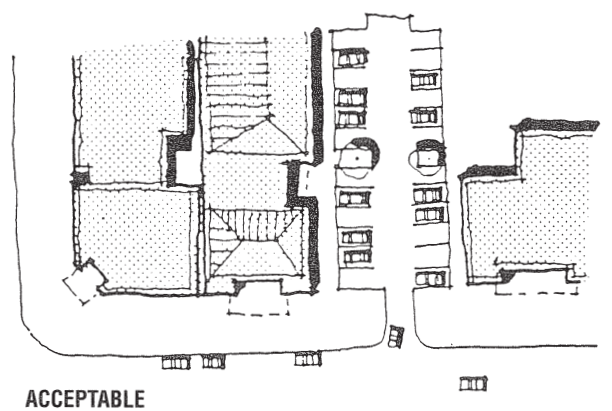

In certain situations, limited streetfront parking lots may be acceptable.

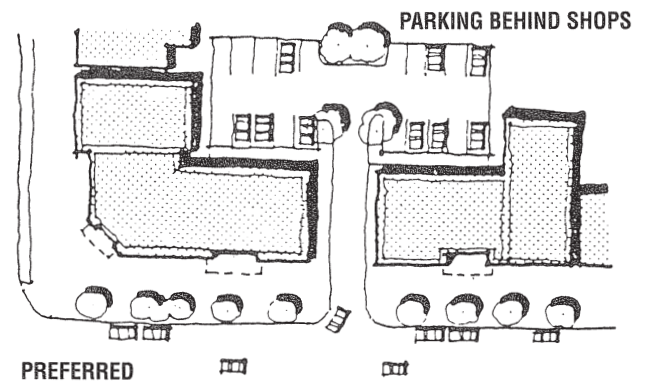

Parking lots located behind shops and offices are preferred.
Figure 4. Parking lot guidelines. Source: Lerable (1995, p. 30). 
but better design strategies can help integrate them into the built environment and improve the public realm. We have already discussed the possibility of locating these lots behind or beside buildings. Another approach, offered by Lynch and Hack (1984), is to limit the size of the parking lots and to drop them "a few feet below pedestrian grade, so that the line of sight passes over the car ... [which] also makes it easier to screen the lots with planting or low walls" (p. 265). Cities can also require that surface parking be screened, as in West Hollywood:

Parking areas adjacent to a public right-of-way shall be provided with landscaping that is designed and maintained to screen cars from the view from the street to a height of forty-two inches, measured from the surface of the parking area. (City of West Hollywood, 2006d)

The reason for limiting the size of parking lots, dropping them partially below grade, and screening them is that conventional parking lots are visually unappealing. Other than concealing them, how can we make them more attractive? One strategy is to use landscaping. In the late 1980s, the Columbus Carscape Competition invited design ideas to improve parking design for a lot in downtown Columbus, Ohio. The winning entry transformed "the parking lot into a park, an urban plaza, through the use of ordinary elements of urban design — patterned pavers and lights under a canopy of trees" (Miller, 1988, p. 40). The winner proposed densely interspersing parking spaces with Bradford pear trees that "do not bear fruit but mark the seasons with white blossoms in the spring and leaves turning red-orange in the fall" (ibid.). The design was inspired by European urban plazas that accommodate cars, market-

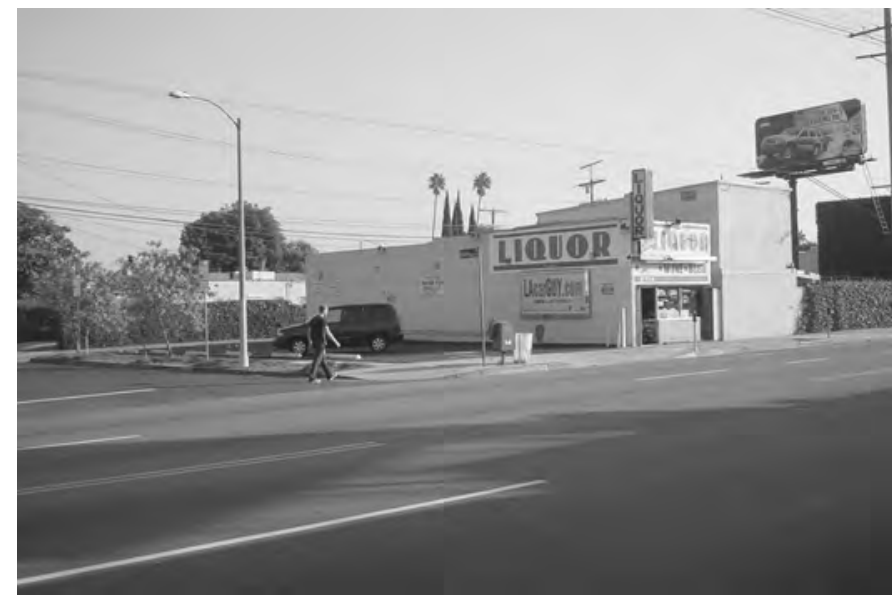

places, and other activities in a single location. Modest landscaping can improve even small parking lots tremendously, and at low cost (see Figure 5).

Many cities have landscaping requirements for parking lots. West Hollywood, for example, has developed a comprehensive strategy. First, the city requires one canopy tree for every eight parking spaces (City of West Hollywood, 2006c). ${ }^{8}$ Second, it defines the number of points awarded for each of a number of landscape and design features, as shown in Table 1. Developers can choose how to achieve the required number of points. This strategy is not overly prescriptive, and allows designers to be creative, but even cities that did not wish to use a point approach could use ideas from Table 1.

In Southern California, solar collectors cover some parking lots (see Figure 6). Some look like high-tech trellises or public art, and feature changing patterns. This makes parking lots more attractive and shades the cars, but is still a costly approach, even taking into consideration the offsetting benefit from the electricity generated.

\section{Parking Structure Design Requirements}

Locating parking in structures occupies less land than surface parking. However parking structure design only occasionally enhances the built environment. In rare circumstances, collaboration between a skilled architect and an enlightened developer leads to a beautiful and functional parking structure, but developers often neglect the architecture and build parking structures as cheaply as possible. Most developers will voluntarily spend money to improve the appearance of a parking structure only to the extent that it increases the value of the residential or commercial development it serves. Because the private economic

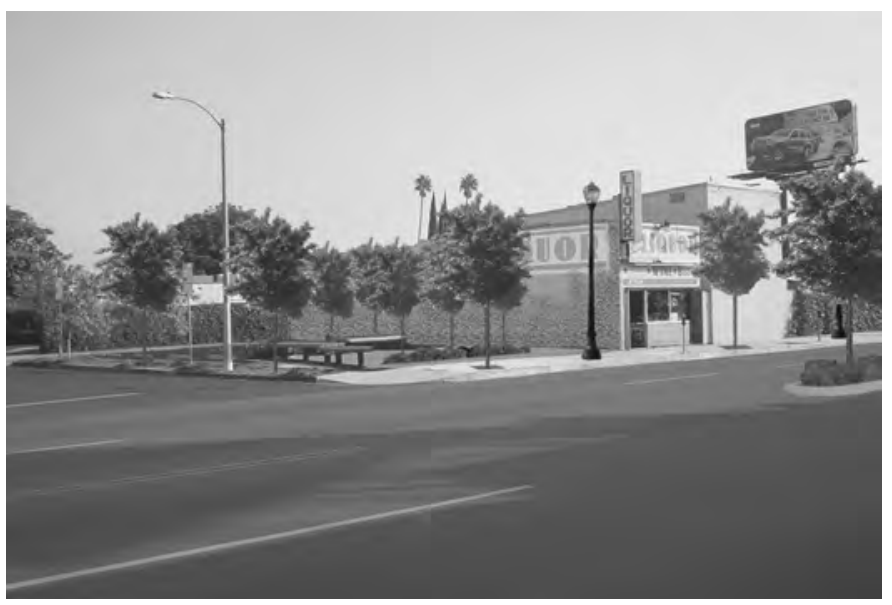

Figure 5. Parking lot without and with landscaping, West Hollywood. (Photo courtesy of Paul Travis). 
Table 1. Landscape and site development features qualifying as credits toward point totals for parking lots in West Hollywood, California.

\begin{tabular}{ll}
$\begin{array}{l}\text { Earned } \\
\text { points }\end{array}$ & Qualifying landscape or site development features \\
\hline 10 & $8 \%$ of site area within parking lot perimeter occupied by landscaping. \\
\hline 4 & Each canopy tree. \\
\hline 4 & Each existing large or well-established tree or specimen plant retained. \\
\hline 6 & Consistent use of vine pockets against walls. \\
\hline 5 & $\begin{array}{l}\text { Pedestrian amenities (e.g., thematic or comprehensive pedestrian lighting scheme, unique decorative materials, art, or ornamental } \\
\text { sculpture or fountains), each. }\end{array}$ \\
\hline 4 & $\begin{array}{l}\text { Surfaces other than asphalt or concrete and permeable surfaces as part of hardscape (does not include planters). Light colored surfaces and } \\
\text { grasscrete are encouraged. }\end{array}$ \\
\hline 5 & Pavement surfaces of rubberized asphalt. \\
\hline
\end{tabular}

\section{The following are available only for parking lots with 51 or more spaces}

20 Integration of circulation, hardscape, walls, landscaping, and lighting into a central design concept approved by the Review Authority.

$5 \quad$ Clearly delineated axis to adjoining buildings or other site relationships.

$5 \quad$ Maximum separation of pedestrian and vehicular travel ways.

$5 \quad$ Transition zones to sidewalk and building-adjacent areas.

$5 \quad$ Ability to use parking lot space in other ways when not being used for parking, with uses and activities deemed compatible with the zoning of the site and surrounding properties (e.g., pedestrian space or basketball court).

6 Decorative perimeter walls with integral architectural elements (e.g., gateways, coping, piers, and ornamental and decorative materials).

Source: City of West Hollywood (2006b)

incentives for good parking design are weak, parking structures need architectural controls and review to ensure good urban design.

One strategy to improve urban design is to build parking structures that look like regular buildings. ${ }^{9}$ This was a common practice in the early part of the last century. A more contemporary approach is to "wrap," or surround, a parking structure with retail or other uses. Dunphy, Myerson, and Pawlukiewicz (2003) suggested that "creative designers can wrap a parking structure with retail shops, eateries, residences, and services, such as dry cleaners" (p. 11). In addition to concealing the parking, this creates a mixeduse development, and patrons who park in the structure provide a built-in clientele for the retail businesses. How- ever, this approach can increase a developer's cost if natural ventilation is not feasible and mechanical ventilation is required. In such cases, cities may offer the developer a higher floor area ratio as compensation. Alternatively, cities can require retail or residential uses only at the street level and some modest architectural details on the upper level facades (see Figure 7). San Diego's zoning ordinance mandates this approach for parking in the CBD: "All enclosed ground level parking areas shall be shielded from adjoining public streets, with such parking areas being separated from the public sidewalk by habitable residential or non-residential space, or utility rooms." (City of San Diego, 2006). 


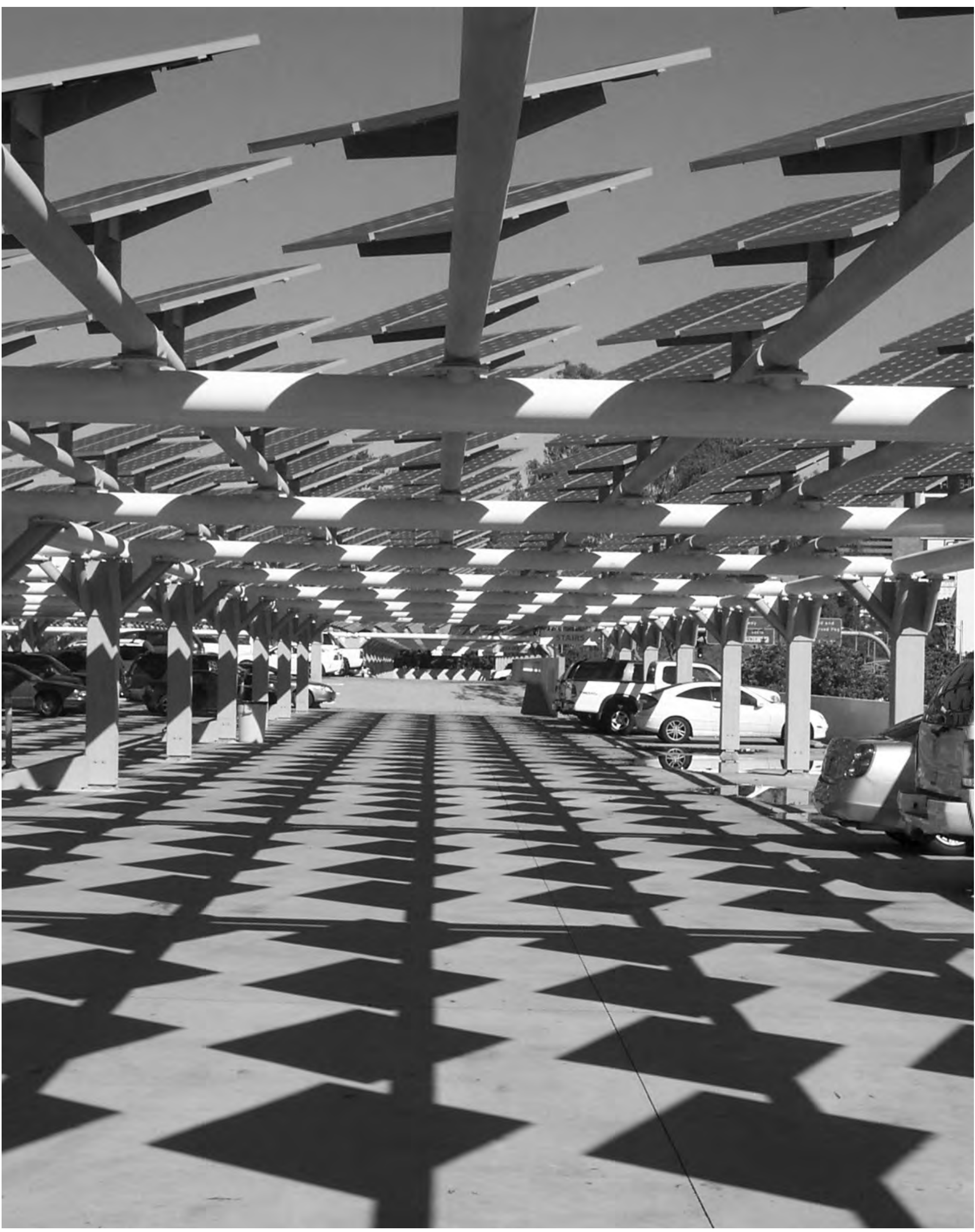

Figure 6. Solar collectors over a parking lot, Los Angeles. 


\section{Garage Door Restrictions}

The importance of improved parking design is not limited to the commercial districts of cities. Parking infrastructure (garages and driveways) can easily overwhelm residential neighborhoods as well. To reduce the impact of parking on the residential streetscape, Carmel restricts the size of all residential garage doors that face a street to the width necessary for a single car: "On sites of less than 6,000 square feet, only a single-car-width garage door shall face the street" (City of Carmel-by-the-Sea, 1998a). As a result, garage doors do not dominate the fronts of houses. Figure 8 shows an example of a resulting facade. Portland, Oregon, limits the length of the garage wall facing the street to no more than $50 \%$ of the entire building façade (Wittenberg, 2002). ${ }^{10}$ Other cities could follow similar strategies, limiting garage frontage but allowing more depth for parking.

Local governments can also restrict the location and design of garages. To prohibit "snout" houses with protruding garages that take up most of the street frontage, Olympia, Washington, requires that garages be located behind the house or stepped back from the facade of a building. To limit the view of garages from the street and to minimize curb cuts that disrupt the sidewalks, Olympia's garage design guidelines recommend that driveways be as narrow as possible and shared where feasible (see Figure 9). Recessed garages and balconies over garage doors also help the doors disappear in the shadows (see Figure 10). Garage sidewalls that face the street can be designed to appear as habitable spaces by incorporating windows and other design elements that are in character with the rest of the dwelling (City of Olympia, 2006).

\section{Conclusion}

Although we criticize the way planners now regulate parking, we do not call for deregulation. Instead, we recommend that planners use their ability to regulate parking more constructively, worrying less about the quantity of parking and more about its quality. Market

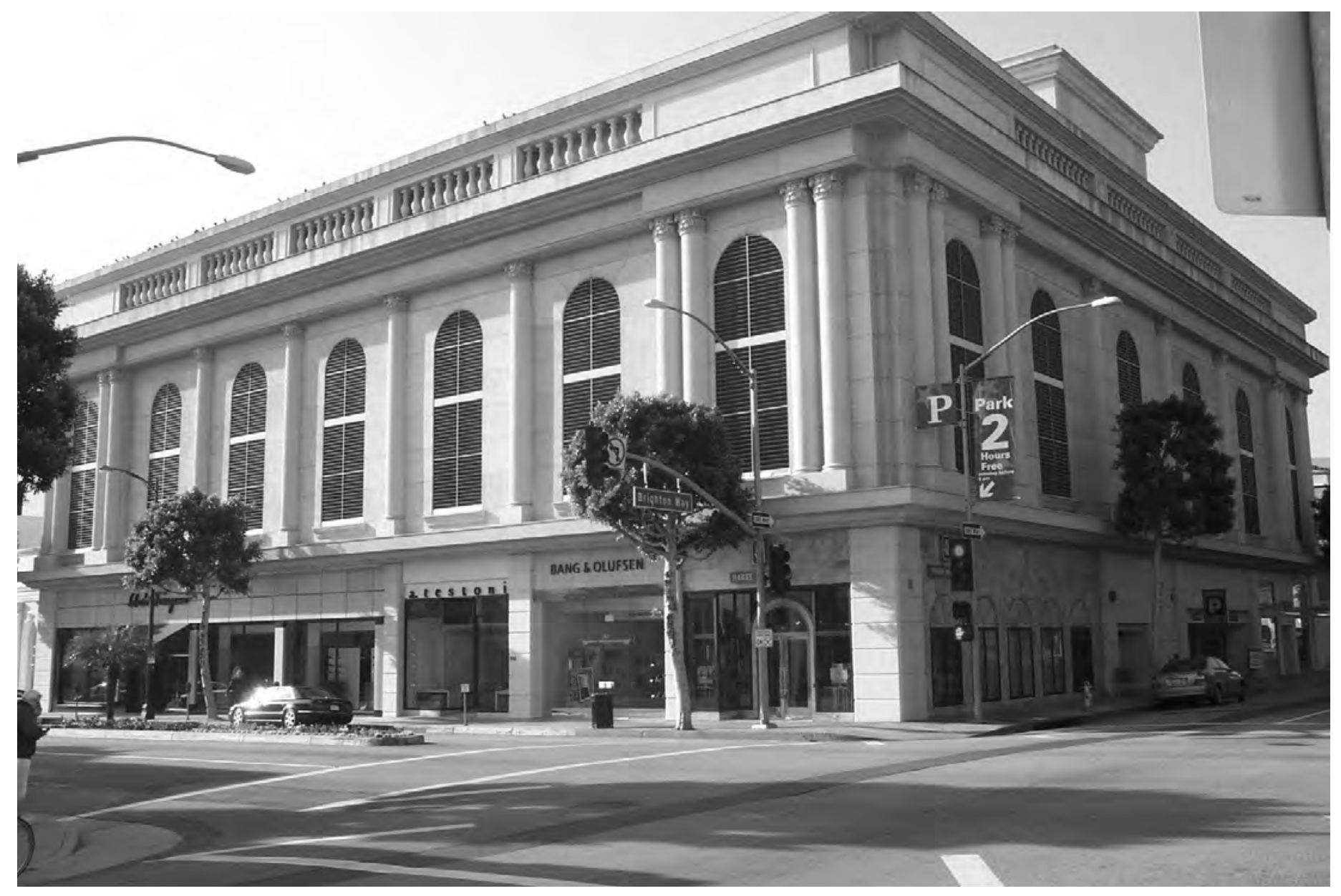

Figure 7. Parking structure with ground-floor retail, Beverly Hills. 
306 Journal of the American Planning Association, Summer 2006, Vol. 72, No. 3

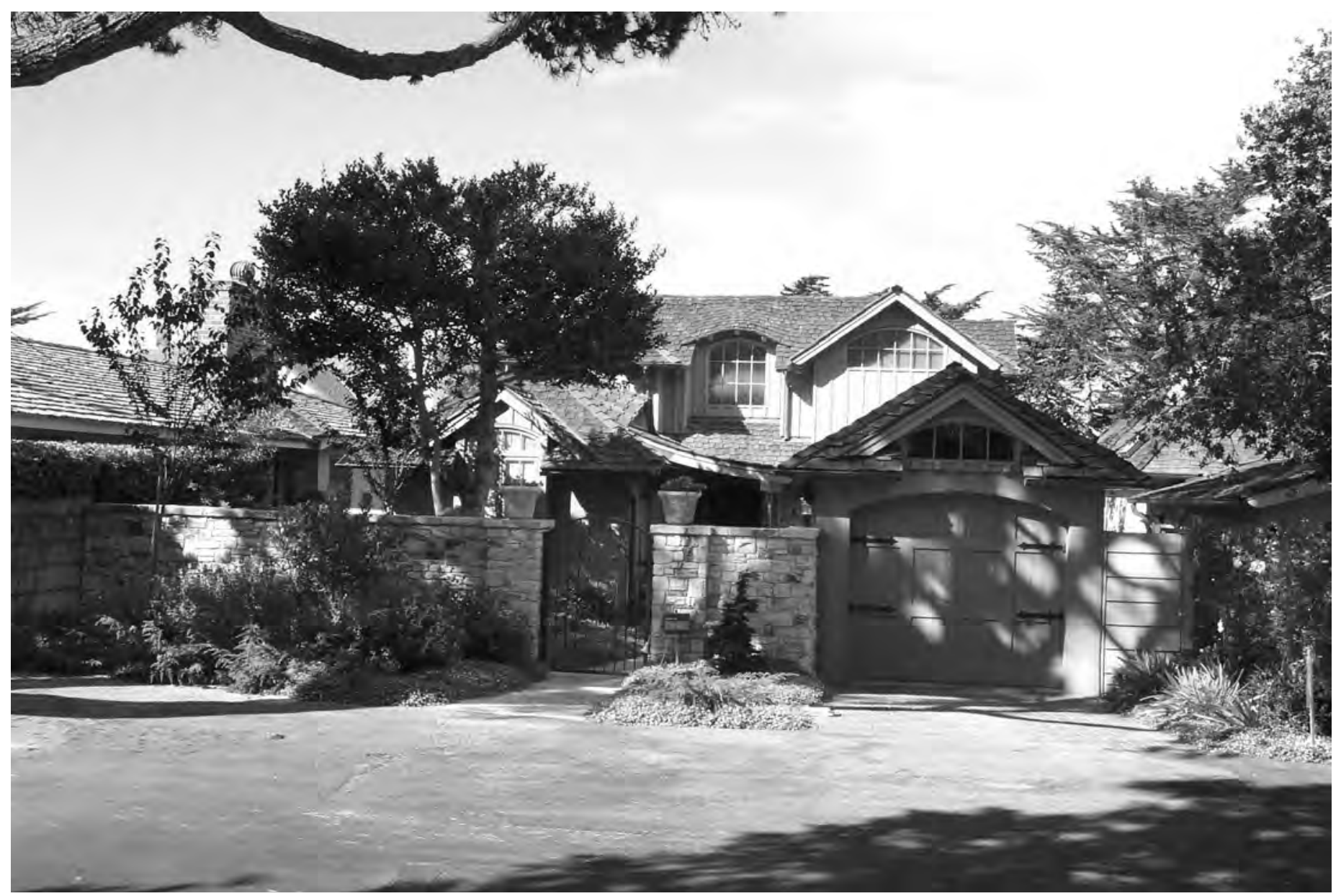

Figure 8. Single-car-width garage, Carmel.

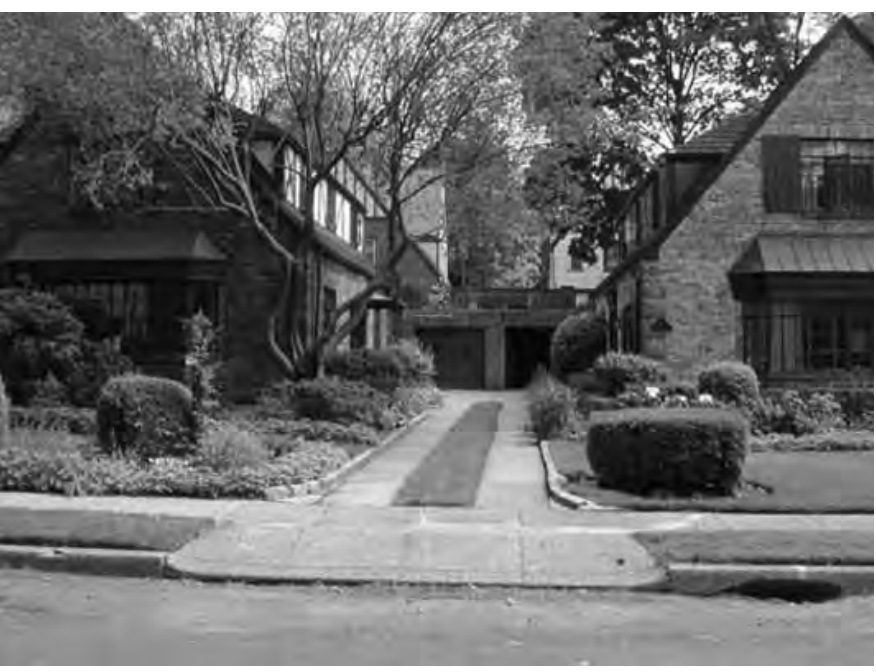

Figure 9. Shared driveway, Forest Hills. (Photo courtesy of Joel Cochran).

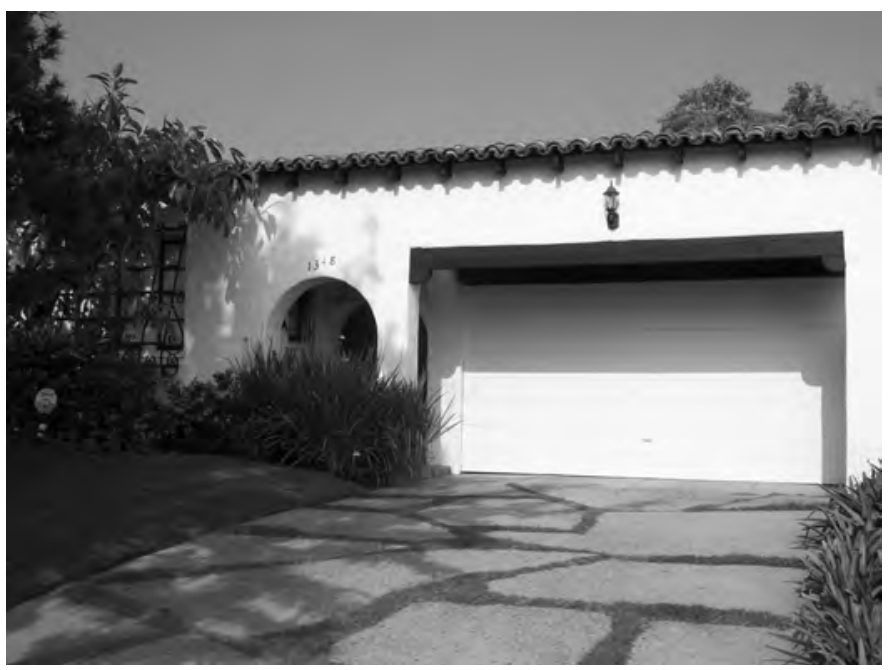

Figure 10. Recessed garage door, Los Angeles. 
forces can ensure an adequate number of parking spaces, but the economic incentives for good parking design are weak. Nonetheless, most local governments strictly regulate parking quantity but ignore its quality. As a result, parking now spoils much of the American landscape.

Even where local governments do regulate the design of parking lots and structures, minimum parking requirements require a massive parking supply that is difficult to camouflage. This article points out places that have put quality ahead of quantity in their regulation of parking, providing examples for other localities. We find at least five different approaches to improving urban design through creative off-street parking requirements: limiting the number of parking spaces; improving the location of parking; and requiring better design of parking lots, parking structures, and residential garages. Just as many cities have adapted zoning codes from other communities, they can use design regulations from other places to improve the quality of their own urban environments. Planners cannot significantly improve the design of cities without reforming local parking requirements to emphasize quality over quantity. While developers may object that better design will cost more, cities can mitigate these costs by reducing or removing minimum parking requirements. Reducing parking alone will improve urban design. As a famous architect once put it, less is more.

\section{Acknowledgements}

We are grateful for the assistance of Steven Crosley, Matthew Dresden, Joseph Holmes, Hiro Iseki, David King, George Kosovich, Michael Manville, Ann McCauley, Andrew Mondschien, Eric Morris, Paul Philley, Lara Regus, Sara Slovin, and Paul Sorensen in editing this manuscript. We also thank Poppy Gilman for helping assemble images and Paul Travis for allowing us to use his illustrations.

\section{Notes}

1. In their illuminating history of how parking lots have affected American cities, Jakle and Sculle (2004) concluded, "Nothing over the past century has proven as disruptive of traditional urban landscape as parking. Perhaps nothing has made American cities less memorable" (p. 8). In his excellent guide to better design of parking lots and structures, Childs (1999) wrote, "The typical design of parking lots as simply a monofunctional expanse of cheap asphalt and a net of white lines is wasteful and destructive. ... parking lots have eaten away cities in the United States like moths devouring a lace wedding gown” (p. xxi). Minimum parking requirements have made this bad situation even worse. 2. In their seminal work Collage City, Rowe and Koetter (1978) criticized the revitalization of cities based entirely on demolition and redevelopment, and made an argument for the preservation of older buildings and styles. 3. The Los Angeles Municipal Code states that for these conversions, "The required number of parking spaces shall be the same as the number of spaces that existed on the site on June 3,1999, and shall be maintained and not reduced" (City of Los Angeles, 2001).

4. Carmel provides several parking lots on the periphery of its downtown.
5. The Urban Land Institute (1983) explains the economics of shared parking.

6. Similarly, the Rochester, New York, Municipal Code states, "parking shall not be permitted between a building and the sidewalk" (City of Rochester, 2005b).

7. Similarly, the Rochester, New York, Municipal Code states, "Parking for single-family, two-family and attached dwellings in all districts shall be limited to no more than three vehicles for each dwelling unit. No parking for such residential uses shall be located in the required side or front yard setback except in a legal driveway that provides access to the rear yard, a detached or attached garage.” (City of Rochester, 2005a). 8. Similarly, the Rochester, New York, Municipal Code states, "A minimum of one landscaped area with a minimum size of 162 square feet (approximately nine feet by 18 feet) shall be provided for every 15 parking spaces and developed as islands within the parking surface area" (City of Rochester, 2005c).

9. West Hollywood requires that "Parking structures visible from street frontages shall be designed to be compatible with architectural character and quality of adjacent buildings and shall not adversely impact abutting pedestrian sidewalks" (City of West Hollywood, 2006e).

10. Similarly, New Jersey requires cities to calculate the number of offstreet parking spaces in a way that reduces the garage frontage. A one-car garage and driveway combination counts as two parking spaces if the length of the driveway is at least 18 feet between the face of the garage door and the right-of-way (State of New Jersey, 2006).

\section{References}

Alexander, C., Ishikawa, S., \& Silverstein, M. (1977). A pattern language. New York: Oxford University Press.

Barnett, J. (1974). Urban design as public policy: Practical methods for improving cities. New York: Architectural Record, McGraw-Hill.

Calthorpe, P. (1993). The next American metropolis: Ecology, community, and the American dream. New York: Princeton Architectural Press. Childs, M. (1999). Parking spaces: A design, implementation, and use manual for architects, planners, and engineers. New York: McGraw-Hill. City of Carmel-by-the-Sea, California. (1998a). City of Carmel-by-theSea Municipal Code, $\$ 17.24 .120$ C.

City of Carmel-by-the-Sea, California. (1998b). City of Carmel-bythe-Sea Municipal Code, $\$ 17.38 .030$ A.

City of Los Angeles, California. (2001). Los Angeles Municipal Code $\$ 12.22$ A 26(g)(3).

City of Olympia, Washington. (2006). Olympia Municipal Code $\$ 18.05$ A.280 B 3 .

City of Portland, Oregon. (2006). Portland Municipal Code $\$ 33.266 .119$ B 3.

City of Rochester, New York. (2005a). Rochester Municipal Code $\$ 120-173$ F 1 (c).

City of Rochester, New York. (2005b). Rochester Municipal Code $₫$ 120-173 F 1(d).

City of Rochester, New York. (2005c). Rochester Municipal Code $\$ 120-173$ F 2(f).

City of San Diego, California. (2006). San Diego Municipal Code $\$ 151.0313(\mathrm{~h})(1)$.

City of San Francisco, California. (2006). San Francisco Municipal Code $\$ 156(\mathrm{~h})$.

City of SeaTac, Washington. (2006). SeaTac Municipal Code

$\$ 15.13 .110$ A 4(a).

City of West Hollywood, California. (2006a). West Hollywood Municipal Code $\$ 19.28 .090$ D 1(a). 
308 Journal of the American Planning Association, Summer 2006, Vol. 72, No. 3

City of West Hollywood, California. (2006b). West Hollywood Municipal Code $\$ 19.28 .100$ (Table 3-9).

City of West Hollywood, California. (2006c). West Hollywood Municipal Code $\$ 19.28 .100$ B 1.

City of West Hollywood, California. (2006d). West Hollywood Municipal Code $\$ 19.28 .100$ B 3(a).

City of West Hollywood, California. (2006e). West Hollywood Municipal Code $\$ 19.28 .110$ B 1 .

Dunphy, R., Myerson, D., \& Pawlukiewicz, M. (2003). Ten principles for successful development around transit. Washington, DC: Urban Land Institute.

Jakle, J., \& Sculle, K. (2004). Lots of parking: Land use in a car culture. Charlottesville, VA: University of Virginia Press.

Lerable, C. (1995). Preparing a conventional zoning ordinance (Planning Advisory Service Report No. 460). Chicago: American Planning Association.

Liebs, C. (1985). Main street to miracle mile: American roadside architecture. Boston: Little, Brown.
Longstreth, R. (1992). The perils of a parkless town. In M. Wachs \& M. Crawford (Eds.), The car and the city (pp. 141-153). Ann Arbor, MI: University of Michigan Press.

Lynch, K., \& Hack, G. (1984). Site planning (3rd ed.). Boston: MIT Press.

Miller, C. (1988). Carscape, a parking handbook. Columbus, OH: Washington Street Press.

Rowe, C., \& Koetter, F. (1978). Collage city. Boston: MIT Press. Shoup, D. (2005). The high cost of free parking. Chicago: Planners Press. Smith, M. (1996, September). Circle Centre: How parking helped make urban retail/entertainment development work. Parking, 25-33. State of New Jersey. (2006). New Jersey Administrative Code $\$$ 5:21$4.14(\mathrm{~d})(2)$.

Urban Land Institute. (1983). Shared parking. Washington, DC: Author.

Wittenberg, J. (2002, August). Garages: Not just for cars anymore. Zoning News, 1-5. 